GLASTOO FUtGR:

葛

要

$H$

点

点
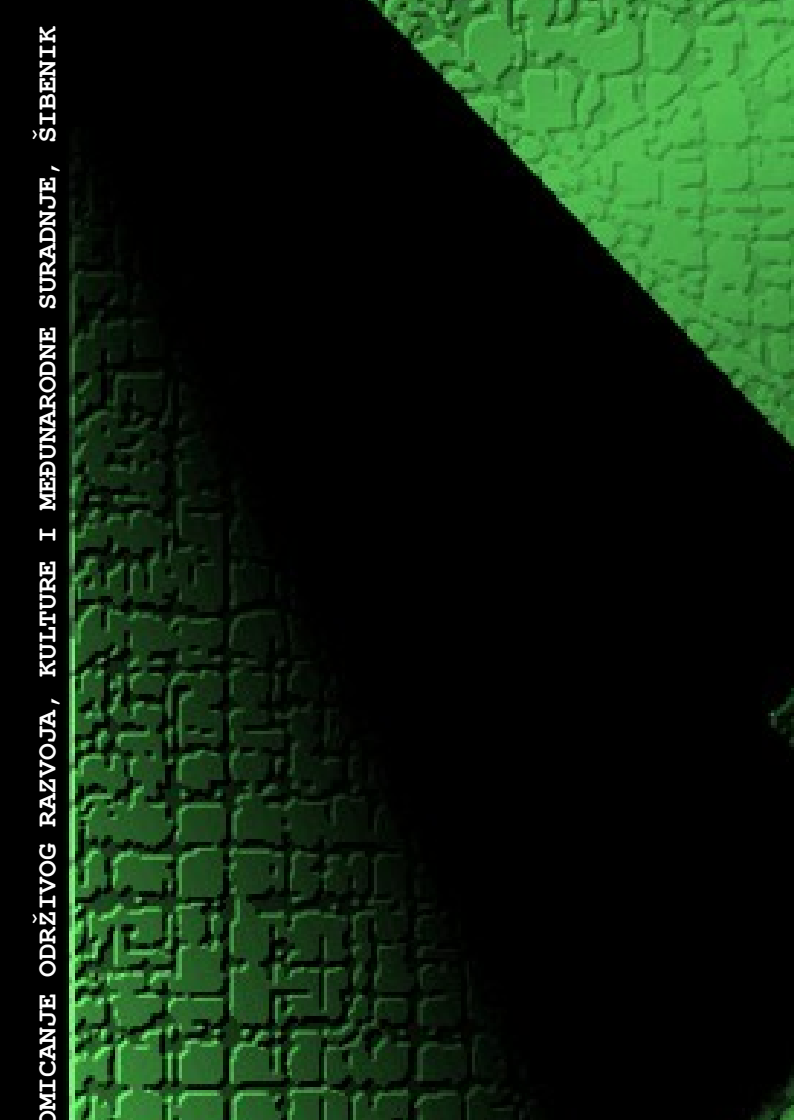


\section{Glasilo Future}

\section{Stručno-znanstveni časopis}

Nakladnik:

FUTURA

\section{FuTU}

Sjedište udruge: Šibenik
Adresa uredništva:

Bana Josipa Jelačića 13 a, 22000 Šibenik, Hrvatska / Croatia

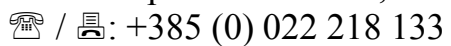

凶: urednistvo@gazette-future.eu / editors@gazette-future.eu (7): www.gazette-future.eu

Uređivački odbor / Editorial Board:

Doc. dr. sc. Boris Dorbić, v. pred. - glavni i odgovorni urednik / Editor-in-Chief

Emilija Friganović, dipl. ing. preh. teh., v. pred. - zamjenica g. i o. urednika / Deputy Editor-in-Chief

Ančica Sečan Matijaščić, mag. act. soc. - tehnička urednica / Technical Editor

Antonia Dorbić, mag. art. - zamjenica tehničke urednice / Deputy Technical Editor

Prof. dr. sc. Željko Španjol

Mr. sc. Milivoj Blažević

Vesna Štibrić, dipl. ing. preh. teh.

Međunarodno uredništvo / International Editorial Board:

Prof. dr. sc. Kiril Bahcevandziev - Portugalska Republika (Instituto Politécnico de Coimbra)

Prof. dr. sc. Martin Bobinac - Republika Srbija (Šumarski fakultet Beograd)

Prof. dr. sc. Zvezda Bogevska - Republika Sjeverna Makedonija (Fakultet za zemjodelski nauki i hrana Skopje)

Dario Bognolo, mag. ing. - Republika Hrvatska (Veleučilište u Rijeci)

Prof. dr. sc. Agata Cieszewska - Republika Poljska (Szkoła Główna Gospodarstwa Wiejskiego w Warszawie)

Dr. sc. Bogdan Cvjetković, prof. emeritus - Republika Hrvatska (Agronomski fakultet Zagreb)

Prof. dr. sc. Duška Ćurić - Republika Hrvatska (Prehrambeno-biotehnološki fakultet Zagreb)

Prof. dr. sc. Margarita Davitkovska - Republika Sjeverna Makedonija (Fakultet za zemjodelski nauki i hrana Skopje)

Prof. dr. sc. Dubravka Dujmović Purgar - Republika Hrvatska (Agronomski fakultet Zagreb)

Prof. dr. sc. Josipa Giljanović - Republika Hrvatska (Kemijsko-tehnološki fakultet u Splitu)

Prof. dr. sc. Semina Hadžiabulić - Bosna i Hercegovina (Agromediteranski fakultet Mostar)

Prof. dr. sc. Péter Honfi - Mađarska (Faculty of Horticultural Science Budapest)

Prof. dr. sc. Valeria Ivanova - Republika Bugarska (Fakultet za lozaro - gradinarstvo Plovdiv)

Prof. dr. sc. Mladen Ivić - Bosna i Hercegovina (Univerzitet PIM)

Doc. dr. sc. Orhan Jašić - Bosna i Hercegovina (Filozofski fakultet Tuzla)

Prof. dr. sc. Tajana Krička - Republika Hrvatska (Agronomski fakultet Zagreb)

Doc. dr. sc. Dejan Kojić - Bosna i Hercegovina (Univerzitet PIM)

Slobodan Kulić, mag. iur. - Republika Srbija (Srpska ornitološka federacija i Confederation ornitologique mondiale)

Prof. dr. sc. Biljana Lazović - Crna Gora (Biotehnički fakultet Podgorica)

Prof. dr. sc. Branka Ljevnaić-Mašić - Republika Srbija (Poljoprivredni fakultet Univerziteta u Novom Sadu)

Doc. dr. sc. Zvonimir Marijanović - Republika Hrvatska (Kemijsko-tehnološki fakultet u Splitu)

Doc. dr. sc. Ana Matin - Republika Hrvatska (Agronomski fakultet Zagreb)

Prof. dr. sc. Bosiljka Mustać - Republika Hrvatska (Sveučilište u Zadru)

Hrv. akademik prof. dr. sc. Stanislav Nakić - Bosna i Hercegovina (Sveučilište Hercegovina Mostar)

Sandra Popović, mag. ing. - Republika Srbija (Poljoprivredni fakultet Beograd)

Doc. dr. sc. Bojan Simovski - Republika Sjeverna Makedonija (Fakultet za šumarski nauki, pejzažna arhitektura i

ekoinženering "Hans Em" Skopje)

Prof. dr. sc. Davor Skejić - Republika Hrvatska (Građevinski fakultet Zagreb)

Doc. dr. sc. Milan Stanković - Republika Srbija (Univerzitet u Kragujevcu)

Akademik prof. dr. sc. Refik Šećibović - Bosna i Hercegovina (Visoka škola za turizam i menadžment Konjic)

Prof. dr. sc. Andrej Šušek - Republika Slovenija (Fakulteta za kmetijstvo in biosistemske vede Maribor)

Prof. dr. sc. Elma Temim - Bosna i Hercegovina (Agromediteranski fakultet Mostar)

Mr. sc. Merima Toromanović - Bosna i Hercegovina (Biotehnički fakultet Univerziteta u Bihaću)

Doc. dr. sc. Ivana Vitasović Kosić - Republika Hrvatska (Agronomski fakultet Zagreb)

Doc. dr. sc. Ana Vujošević - Republika Srbija (Poljoprivredni fakultet Beograd)

Prof. dr. sc. Vesna Židovec - Republika Hrvatska (Agronomski fakultet Zagreb)

Lektura i grafička priprema: Ančica Sečan Matijaščić, mag. act. soc.

Objavljeno: 31. prosinca 2019. godine.

C̆asopis izlazi u elektroničkom izdanju dva puta godišnje, krajem lipnja i prosinca, a predviđena su i dva interdisciplinarna specijalna izdanja tijekom godine iz STEM i ostalih znanstvenih/umjetničkih područja.

C̆asopis je besplatan. Rukopisi i recenzije se ne vraćaju i ne honoriraju.

Umnožavanje (reproduciranje), stavljanje u promet (distribuiranje), priopćavanje javnosti, stavljanje na raspolaganje javnosti odnosno prerada u bilo kojem obliku nije dopuštena bez pismenog dopuštenja Nakladnika.

Sadržaj objavljen u Glasilu Future može se slobodno koristiti u osobne i obrazovne svrhe uz obvezno navođenje izvora. 


\section{Glasilo Future}

\section{Stručno-znanstveni časopis}

FUTURA - stručno-znanstvena udruga za promicanje održivog razvoja, kulture i međunarodne suradnje, Bana Josipa Jelačića 13 a, 22000 Šibenik, Hrvatska

(2019) 2 (4) 01-74

\section{SADRŽAJ:}

Izvorni znanstveni rad (original scientific paper)

Str.

Žana Delić, Ivana Vuković, T. Svalina, M. Šuste, Emilija Friganović, Mladenka Šarolić,

B. Dorbić

Isparljivi spojevi vina od maline

Volatile compounds of raspberry wines

Emilija Friganović, D. Anić, Ančica Sečan Matijaščić, Mladenka Šarolić, B. Dorbić,

Žana Delić, M. Šuste

Ponašanje i stavovi studenata Veleučilišta "Marko Marulić" u Kninu o funkcionalnim

napitcima

Behavior and attitudes of students of the Marko Marulić Polytechnic of Knin toward

functional beverages

\section{Prethodno priopćenje (preliminary communication)}

E. Delić, B. Dorbić, Nađa Buturović, Azra Bostandžić, Almina Tahirović

Prikaz modela za održavanje terenske nastave iz primijenjene botanike i ekologije

A presentation of a model for teaching field courses in Applied Botany and Ecology

\section{Pregledni rad (scientific review)}

\section{B. Dorbić}

Sanacija i revitalizacija drvoreda bijelog duda (Morus alba L.) na prostoru luka Vrnaža Istočni (središnji) dio luke u Šibeniku

Rehabilitation and revitalization of the white mulberry tree (Morus alba L.) in the area of port Vrnaža - East (central) part of the port in Šibenik

\section{Stručni rad (professional paper)}

\section{Ž. Zrno, Ivana Pintur}

Elementarne funkcije u poljoprivredi

Elementary functions in agriculture

\section{Nekategorizirani rad (uncategorised paper)}

Zdenka Bilušić

Prikaz izložbe

Review of exhibition 
E. Delić, B. Dorbić, Nađa Buturović, Azra Bostandžić, Almina Tahirović / Prikaz modela za održavanje terenske nastave iz primijenjene botanike i ekologije / Glasilo Future (2019) 2 (4) 21-35

\title{
Prikaz modela za održavanje terenske nastave iz primijenjene botanike i ekologije
}

\section{A presentation of a model for teaching field courses in Applied Botany and Ecology}

\author{
Emir Delić ${ }^{1}$, Boris Dorbić ${ }^{2}$ Nađa Buturović ${ }^{3}$, Azra Bostandžić ${ }^{3}$, Almina Tahirović ${ }^{3}$ \\ prethodno priopćenje (preliminary communication)
}

doi: $10.32779 /$ gf.2.4.3

\section{Sažetak}

Terenska nastava je specifični oblik nastave s ciljem da bi se što učinkovitije realizirali oni nastavni sadržaji gdje je potrebno promatranje u prirodi kao i neposredni kontakt s izvornom stvarnošću. Kroz ovaj rad će se prikazati jedan model održavanja terenske nastave iz primijenjene botanike s hipotezom da ovaj način održavanja nastave studenti u većoj mjeri podupiru i laganije usvajaju znanja. Botanička sekcija je jedna od sekcija koja djeluje u okviru Internacionalnih bioloških kampova koje se održavaju $\mathrm{u}$ organizaciji Udruženja studenata biologije Prirodno-matematičkog fakulteta Univerziteta $\mathrm{u}$ Sarajevu. Sudionici botaničke sekcije kroz praktičnu i teorijsku nastave dobivaju znanja o biljnim ekosustavima, determinaciji vrsta, njihovom očuvanju te korištenju.

Teoretska nastava se održavala u prostorijama Eko centra "Jezera", a terenska na području Eko centra "Jezera". Temeljem dobivenih rezultata ustanovljeno je da su studenti s ocjenom izvrstan ocijenili kvalitetu nastave iz svih bio-ekoloških područja. Samoprocjena znanja studenata je pokazala da su studenti najbolje ocjene dodijelili nivou znanja iz područja dendrologije. Rezultati anketnog istraživanja su potvrdila početnu hipotezu da ovaj tip nastave studenti u većoj mjeri podupiru i lakše usvajaju nastavno gradivo.

Ključne riječi: terenska nastava, metodika, model, botanika, ekologija.
Abstract
Field courses are a specific form of teaching intended to most effectively deliver the teaching content that requires observation of nature, as well as a direct contact with authentic reality. A model of teaching field courses in Applied Botany has been presented through this paper based upon the hypothesis that students largely support this method of teaching and in this way acquire knowledge more easily. The Botany Section is one of the sections that operates within International Biology

\footnotetext{
${ }^{1}$ Slavne Brigade 71, 77000 Bihać, Bosna i Hercegovina

${ }^{2}$ Veleučilište "Marko Marulić" u Kninu, Odjel Poljoprivreda krša, Krešimirova 30, 22300 Knin, Republika Hrvatska.

*E-mail: boris.dorbic@veleknin.hr

${ }^{3}$ Univerzitet u Sarajevu, Prirodno-matematički fakultet, Zmaja od Bosne 33-35, 71000 Sarajevo, Bosna i

Hercegovina
} 
E. Delić, B. Dorbić, Nađa Buturović, Azra Bostandžić, Almina Tahirović / Prikaz modela za održavanje terenske nastave iz primijenjene botanike i ekologije / Glasilo Future (2019) 2 (4) 21-35

Camps that are held and organized by Biology Students Association of the Faculty of Natural Sciences and Mathematics at the University of Sarajevo. The Botany Section participants are provided knowledge about plant ecosystems, species determination, their preservation and use through both practical and theoretical courses.

Theoretical courses were held at the premises of "Jezera" Eco Centre, while field courses were held outdoors in the area of "Jezera" Eco Centre. Based on the findings, it was determined that students evaluated the quality of the courses in all bioecological fields with the grade excellent. Self-assessment of knowledge acquired by the students showed that students gave the best grades to the knowledge level reached in the field of dendrology. The results of the survey research confirmed the initial hypothesis that this type of teaching is largely supported by students and that in this way they more easily master the teaching content.

Key words: field teaching, methodology, model, botany, ecology.

\section{Uvod}

Pod izvanučioničkom nastavom smatra se svaki oblik nastave koji se održava izvan učionice, a za isto se koristi različito nazivlje: terenska nastava, nastavna ekskurzija, šetnja, izlet i slično (Takač, 2013., prema., Sever et al., 2017). To je specifični oblik nastave s ciljem da bi se što učinkovitije realizirali oni nastavni sadržaji za koje je potrebno promatranje u prirodi i kontakt s izvornom stvarnošću (Husanović-Pejnović, 2011., prema., Sever et al., 2017).

Važnost izvanučioničke nastave i terenske nastave u biologiji veoma je važna i poznata te se nalazi u studijskim programima za nastavnike biologije (Bogut et al., 2017). Aktivno učenje, razvoj istraživačkih vještina te generičkih kompetencija poput organiziranja, planiranja i suradnje, osnovne su odlike terenske nastave (Šag et al., 2016).

Predavačku - frontalnu nastavu iz "tradicionalnih škola", potrebno je zamijeniti nastavom sa suvremenim metodama za potrebe današnjih učenika kako bismo ih potaknuli na samostalnost $u$ učenju i potaknuli njihovu kreativnost (Glaser, 2005., prema., Žujo Zekić et al., 2017).

Velika odgovornost uspješne izvanučioničke nastave u prirodi leži na učiteljima. Ovakav oblik nastave zahtijeva veću pripremu nastavnika od klasičnog sata u učionici (Sever et al., 2017).

Nauka daje učenicima poticaj za istraživanje svijeta u kojem žive, za eksperimentiranje kojim se povećava sposobnost analiziranja i shvaćanja svijeta oko sebe, pomaže im da razvijaju osjećaj za složene veze između ljudi i prirode (Žujo Zekić et al., 2017).

U novije vrijeme korištenjem suvremene obrazovne tehnologije u nastavi biologije smanjilo se ili potpuno isključilo korištenje prirodnog materijala (Ademović et al., 2018).

Botanička sekcija je jedna od desetak bioloških sekcija, koja djeluje u okviru Internacionalnih bioloških kampova koje se održavaju jednom ili nekoliko puta godišnje u organizaciji Udruženja studenata biologije Prirodno-matematičkog fakulteta Univerziteta u Sarajevu (Bosna i Hercegovina). 
E. Delić, B. Dorbić, Nađa Buturović, Azra Bostandžić, Almina Tahirović / Prikaz modela za održavanje terenske nastave iz primijenjene botanike i ekologije / Glasilo Future (2019) 2 (4) 21-35

Botanička sekcija ima znanstveno-istraživački karakter, koja ima za cilj edukaciju sudionika/studenata o vegetaciji i ekološkim faktorima istraživanog područja. Nastava se održava kroz teoretski i praktični dio na terenu.

Sudionici botaničke sekcije kroz praktični i teorijski dio nastave dobivaju znanja o biljnim ekosustavima, determinaciji vrsta, njihovom očuvanju i korištenju. Ovakav tip nastave koji nude Internacionalni biološki kampovi, uvelike doprinose proširenju i utvrđivanju stečenih znanja $\mathrm{s}$ "bioloških" fakulteta te pripremaju studente za samostalno istraživanje nakon stečene diplome.

Područje Eko-centra "JezeraW u Bijeljini dio je starog drinskog toka, a smješteno je na Pavlovića putu, prema graničnom prijelazu s Republikom Srbijom. Od centra Bijeljine udaljeno je 12 kilometara. Posjetiteljima nudi različite sadržaje tijekom boravka u prirodi: organiziranje namjenskih radionica i kampova, istraživanje barskih ekosustava, uz upoznavanje s ugroženim biljnim i životinjskih vrstama donjeg toka i ušća rijeke Drine itd. Cilj rada je prikazati jedan model održavanja terenske nastave iz primijenjene botanike s pretpostavkom da ovakav tip nastave studenti u većoj mjeri podupiru i lakše usvajaju dobivena znanja.

\section{Materijali i metode}

Terenska nastava je održana u sklopu IX Internacionalnog biološkog kampa Eko-centar "Jezera" u Bijeljini. Studentima su na terenu objašnjeni vegetacijski pojasevi, fitocenološke snimke, metode determinacije, sakupljanja, stratifikacije te načina skladištenja sjemena drvenastih vrsta. Sudionicima je objašnjena i determinaciju drvenastih vrsta pomoću listova, habitusa, izbojaka, pupova, kore i cvjetova. U okviru terenske nastave studenti su upoznati i s najznačajnijim tipovima šumskih tala, koji su prisutni u nizinskom i brdskom vegetacijskom pojasu, kao i klimatskim uvjetima istraživanog područja.

Teoretska nastava se odvijala u prostorijama Eko centra "Jezera", a terenska na širem području Eko centra "Jezera" u nizinskom vegetacijskom pojasu (70 $\mathrm{m} \mathrm{n}$. v.), duž obala jezera i bara, zatim na planini Majevici, koja obuhvaća brdski vegetacijski pojas (700 m n. v.), u termofilnim šumama. Sudionici terenske nastave/studenti trenutno pohađaju Prirodno-matematički fakultet Univerziteta u Sarajevu, I ciklus, odsjek za biologiju, na studijskim programima Ekologija, Genetika i Mikrobiologija. Njihovo dosadašnje znanje iz botanike je bilo na zavidnom nivou.

Nastavu je održavao bsc. šumarstva s iskustvom u visokoškolskoj nastavi prema silabusu za predmete (Tablica 1).

Prilikom izvođenja terenske i teoretske nastave studenata korištena je sljedeća literatura:

Dendrologija (Idžojtić, 2005; Idžojtić, 2009; Idžojtić, 2013; Franjić i Škvorc, 2010; Šilić, 1990-a; Šilić, 1990-b; Šilić, 2005.); Šumarska fitocenologija (Medak, 2018; Stefanović, 1977; Vukelić et al., 
E. Delić, B. Dorbić, Nađa Buturović, Azra Bostandžić, Almina Tahirović / Prikaz modela za održavanje terenske nastave iz primijenjene botanike i ekologije / Glasilo Future (2019) 2 (4) 21-35

2001; Vojniković et al., 2017.); Šumsko sjemenarstvo (Dorbić et al., 2018; Gurda, 1999; Kajba i Balian, 2007; Mataruga et al., 2013; Mekić, 1997; Mekić, 1998.)

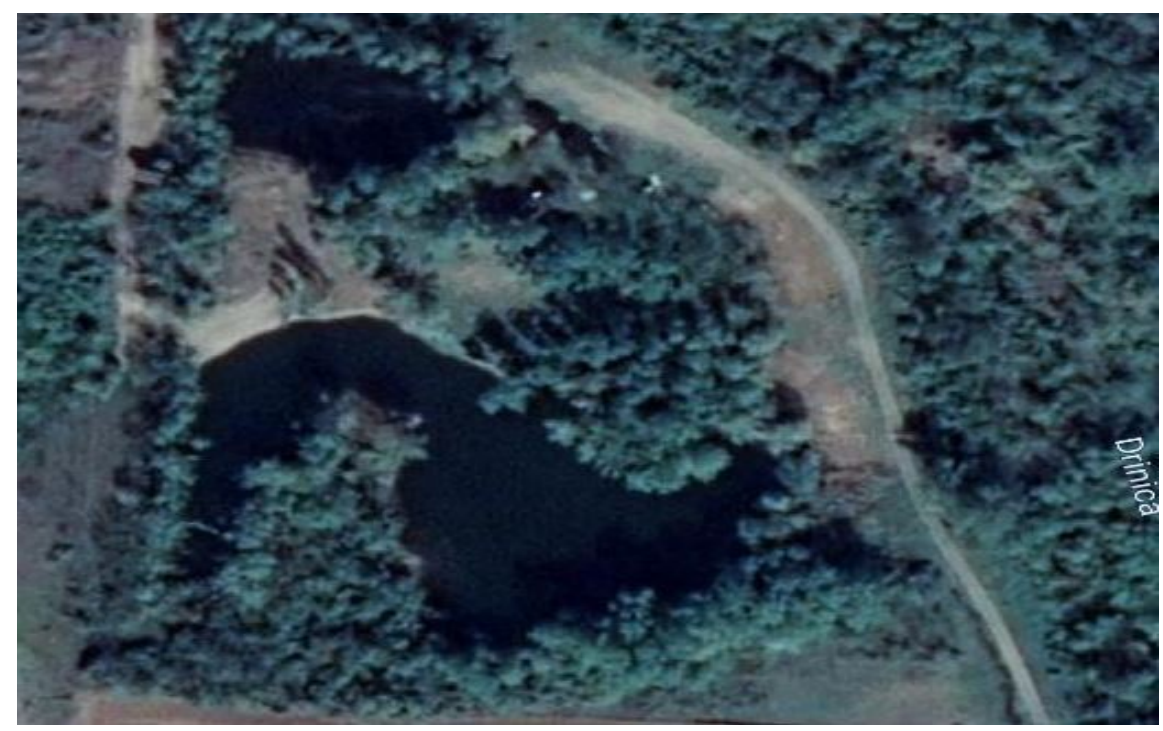

Slika 1. Geografski prikaz istraživanog područja (Izvor: Google Earth)

Figure 1. Geographical representation of the study area (Source: Google Earth)

Tablica 1. Sažeti silabus održanih predmeta

Table 1. Summarized syllabus of subjects

\begin{tabular}{|c|c|c|c|}
\hline $\begin{array}{c}\text { Naziv nastavne } \\
\text { jedinice }\end{array}$ & Opis nastavne jedinice & \multicolumn{2}{|c|}{$\begin{array}{l}\text { Način izvođenja nastavne } \\
\text { jedinice / broj sati (h) }\end{array}$} \\
\hline \multirow{2}{*}{ Dendrologija } & \multirow{2}{*}{$\begin{array}{l}\text { Sistematika i nomenklatura drvenastih } \\
\text { vrsta; morfološke, ekološke, horološke i } \\
\text { biološke osobine drvenastih vrsta. }\end{array}$} & Teorijski & 3 \\
\hline & & Praktično & 5 \\
\hline \multirow{2}{*}{$\begin{array}{c}\text { Šumsko } \\
\text { sjemenarstvo }\end{array}$} & \multirow{2}{*}{$\begin{array}{l}\text { Procjene i prognoze uroda, sakupljanja, } \\
\text { čuvanja i determinacije sjemena i plodova } \\
\text { drvenastih vrsta. }\end{array}$} & Teorijski & 4 \\
\hline & & Praktično & 4 \\
\hline \multirow{2}{*}{$\begin{array}{c}\text { Šumarska } \\
\text { fitocenologija }\end{array}$} & \multirow{2}{*}{$\begin{array}{l}\text { Upoznavanje s biljnim zajednicama; } \\
\text { izrada fitocenološkog snimka i tablica. }\end{array}$} & Teorijski & 2 \\
\hline & & Praktično & 6 \\
\hline \multirow{2}{*}{ Osnove pedologije } & \multirow{2}{*}{$\begin{array}{l}\text { Osnovne karakteristike i značaj tla; faktori } \\
\text { i uvjeti koji utječu na nastanak tla. }\end{array}$} & Teorijski & 4 \\
\hline & & Praktično & 4 \\
\hline \multirow{2}{*}{\multicolumn{2}{|c|}{ Ukupno: }} & Teorijski & 13 \\
\hline & & Praktično & 19 \\
\hline
\end{tabular}

Kao izvor primarnih podataka korišteno je i anketno ispitivanje. Cilj navedenog bilo je istražiti percepciju o kvaliteti, interesu i korisnosti terenske nastave iz područja dendrologije i ekologije šuma, kao i samoprocjena znanja studenata iz navedenih područja. 
E. Delić, B. Dorbić, Nađa Buturović, Azra Bostandžić, Almina Tahirović / Prikaz modela za održavanje terenske nastave iz primijenjene botanike i ekologije / Glasilo Future (2019) 2 (4) 21-35

Anketno ispitivanje je provedeno u drugoj polovici 2019. godine na uzorku od 8 ispitanika (7 žena i 1 muškarac), od kojih je 7 ispitanika bilo s područja Sarajevskog kantona, a 1 ispitanik je bio iz ostalih gradova i naselja Bosne i Hercegovine.

Starosna struktura uzorka bila je od 21 do 25 godina. U svrhu statističke izrade korištena je petostupanjska ljestvica s vrijednostima od 1 do 5 (1 - nedovoljan, 2 - dovoljan, 3 - dobar, 4 - vrlo dobar i 5 - odličan).

Obrada podataka provedena je mjerilima centralne tendencije tj. na osnovu izračuna aritmetičke sredine, standardne devijacije i varijance. Statistička obrada podataka je izrađena u programu SPSS 14.

\section{Rezultati i diskusija}

\section{Kratki prikaz održane terenske nastave}

\section{Šumarska fitocenologija}

S obzirom na područje Eko-centra "Jezera" koje se nalazi u nizinskom vegetacijskom pojasu

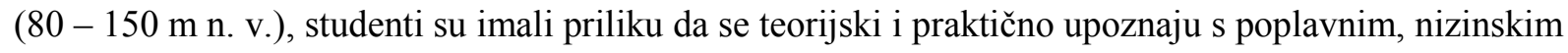
šumama, tj. tipičnom močvarnom, higrofilnom vegetacijom, tzv. ritskim šumama (tipovi šumske vegetacije koja se razvija uz riječne obale, na naplavnim tlima i periodično se poplavljuje, kao što su šume bijele vrbe (Salix alba L.), bijele (Populus alba L.) i crne topole (Populus nigra L.), poljskog jasena (Fraxinus angustifolia Vahl.), crne johe (Alnus glutinosa L.), hrasta lužnjaka (Quercus robur L.) itd.). Potom su upoznati i s zakonitostima nastanka, razvitka i propadanja biljnih zajednica, sukcesijama, sindinamskim jedinicama, arealom biljnih vrsta i zajednica, klimatskim čimbenicima (svjetlost, toplina, voda, vlaga, vjetar) te edafskim i orografskim faktorima.

$\mathrm{Na}$ području planine Majevice studenti su upoznati i s brdskim vegetacijskim pojasom, gdje su izučavali brdske, kserotermne šume hrasta medunca (Quercus pubescens Wild.) i hrasta cera (Quercus cerris L.) (500 m n. v.), kao i kulturu crnog bora, te ostale termofilne i kserotermne biljne vrste, tipove tala, klimatske, orografske i edafske faktore i način izrade fitocenološkog snimka.

\section{Šumsko sjemenarstvo}

U okviru ove nastavne jedinice studenti su usvojili teoretska znanja o determinaciji različitih sjemena i plodova najvažnijih autohtonih šumskih vrsta i nekih egzotičnih (alohtonih) vrsta (Slika 2). Dobili su i osnovna teorijska znanja o proizvodnji sadnog materijala, stratifikaciji, skladištenju i transportu šumskog sjemena, načinu klijanja i patogenima sjemena. Upoznali su se i s procjenom i prognozom uroda sjemena, načinom sakupljanja i sjetve sjemena, vrstama sjemena, objektima za proizvodnju šumskog sjemena i načinima ocjenjivanja zrelosti sjemena. 
E. Delić, B. Dorbić, Nađa Buturović, Azra Bostandžić, Almina Tahirović / Prikaz modela za održavanje terenske nastave iz primijenjene botanike i ekologije / Glasilo Future (2019) 2 (4) 21-35

$\mathrm{Na}$ terenskim istraživanjima, studenti su imali zadatak prikupiti sjemena koja su bila dostupna na istraživanom području, utvrditi tip sjemena i plodova, stupanj zrelosti, sadržaj vlage u sjemenu, stupanj uroda sjemena i način transporta do rasadnika. Od važnijih šumskih vrsta s kojima su se studenti detaljnije upoznali kako teorijski, tako i praktično, jesu: mezijska bukva (Fagus moesiaca (Domin, Maly) Czecz.), obična smreka (Picea abies (L.) H. Karst.), ilirski crni bor (Pinus nigra subsp. illyrica), hrast medunac (Quercus pubescens Willd.), hrast cer (Quercus cerris L.), obična jela (Abies alba Mill.) i druge.

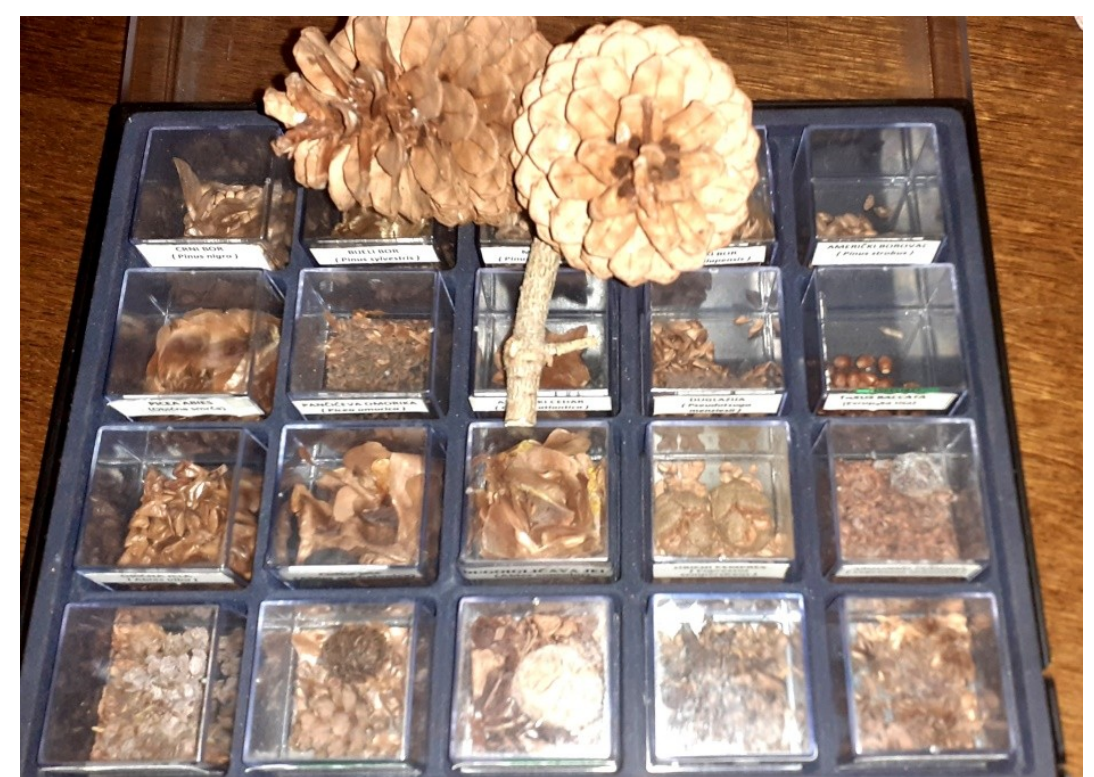

Slika 2. Zbirka šumskog sjemena za edukaciju studenata (Foto: Emir Delić)

Figure 2. Forest seed collection for student education (Photo: Emir Delić)

\section{Dendrologija}

U okviru ovog područja studenti su se teorijski i praktično upoznali s najvažnijim autohtonim i alohtonim drvenastim vrstama koje rastu u užoj okolini istraživanog područja. Tijekom terenske nastave stekli, su nova znanja o morfologiji potonjih vrsta, njihovim ekološkim zahtjevima, arealu, biološkim karakteristikama i gospodarskoj važnosti. Na praktičnim istraživanjima, naučili su raspoznavati drvenaste vrste na osnovi različitih morfoloških karakteristika: habitusa, kore, izbojaka, pupova, listova, cvjetova, sjemena i plodova (češera kod golosjemenjača).

Nakon praktičnog dijela, na terenu su kroz diskusiju raspravljali o stečenom. Na praktičnim radionicama su dobili lisni materijal sa zadatkom da izdvoje izbojak s pupom, sjeme, te oblicu s korom vrste kojoj pripada lisni materijal u čemu su se pokazali uspješnima (Slika 3).

Pored autohtonih (samoniklih) biljnih vrsta, koje rastu na području Eko-centra, studenti su upoznati i s brojnim prisutnim alohtonim (egzotičnim i invanzivnim) biljnim vrstama (načinom njihovog uklanjanja i kontroliranja, kao i s pojedinim biljnim bolestima). 
E. Delić, B. Dorbić, Nađa Buturović, Azra Bostandžić, Almina Tahirović / Prikaz modela za održavanje terenske nastave iz primijenjene botanike i ekologije / Glasilo Future (2019) 2 (4) 21-35

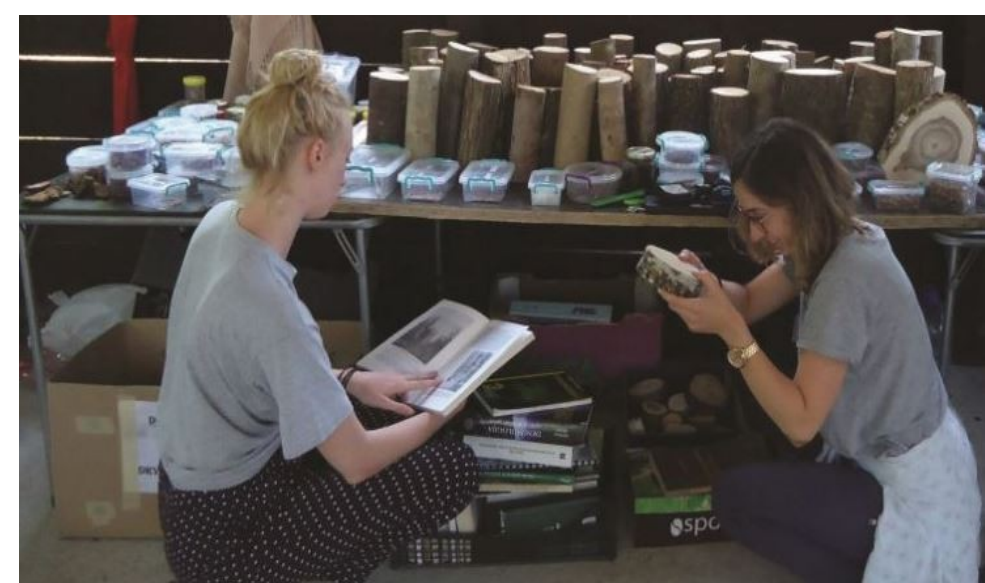

Slika 3. Studenti na dendrološkoj radionici (Foto: Emir Delić)

Figure 3. Students in a dendrology workshop (Photo: Emir Delić)

Tijekom terenskih istraživanja i teorijske edukacije studenti su se upoznali sa biljnim vrstama navedenim u Tablici 2 .

Tablica 2. Biljne vrste obuhvaćene teorijskom i terenskom nastavom

Table 2. Plant species covered by theoretical and field teaching

\begin{tabular}{|c|c|c|c|}
\hline Porodica & Rod $i$ vrsta & Porodica & Rod i vrsta \\
\hline \multirow[t]{4}{*}{ Aceraceae } & Acer campestre L. & \multirow[t]{5}{*}{ Oleaceae } & Fraxinus angustifolia Vahl \\
\hline & $\begin{array}{l}\text { Acer obtusatum Waldst. et Kit. ex } \\
\text { Willd. }\end{array}$ & & Fraxinus excelsior $\mathrm{L}$. \\
\hline & Acer platanoides L. & & Fraxinus ornus L. \\
\hline & Acer pseudoplatanus L. & & Fraxinus pennsylvanica Marshall \\
\hline Anacardiaceae & Cotinus coggygria Scop. & & Ligustrum vulgare L. \\
\hline \multirow[t]{2}{*}{ Apiaceae } & Aegopodium podagraria & \multirow[t]{5}{*}{ Pinaceae } & Picea abies (L.) H. Karst. \\
\hline & Angelica sylvestris & & Picea omorika (Pančić) Purk. \\
\hline Araliaceae & Hedera helix L. & & Pinus mugo Turra \\
\hline Aristolochiaceae & Asarum europaeum & & Pinus nigra J. F. Arnold \\
\hline Asteraceae & Eupatorium cannabinum & & Pinus sylvestris L. \\
\hline \multirow[t]{7}{*}{ Betulaceae } & Alnus glutinosa (L.) Gaertn. & \multirow[t]{3}{*}{ Poaceae } & Brachypodium pinnatum \\
\hline & Betula pendula Roth & & Carex brisoides \\
\hline & Carpinus betulus L. & & Deschampsia caespitosa \\
\hline & Corylus colurna L. & Primulaceae & Lysimachia nummularia \\
\hline & Ostrya carpinifolia Scop. & \multirow[t]{2}{*}{ Ranunculaceae } & Clematis vitalba $\mathrm{L}$. \\
\hline & Corylus avellana $\mathrm{L}$. & & Caltha palustris \\
\hline & Corylus maxima "Purpurea" & Rhamnaceae & Frangula alnus Mill. \\
\hline Caesalpiniaceae & Gleditsia triacanthos $\mathrm{L}$. & \multirow[t]{7}{*}{ Rosaceae } & Crataegus monogyna Jacq. \\
\hline Campanulaceae & Campanula trachelium & & Crataegus nigra Waldst. et Kit. \\
\hline \multirow[t]{3}{*}{ Caprifoliaceae } & Sambucus nigra L. & & Prunus avium (L.) L. \\
\hline & Viburnum lantana $\mathrm{L}$. & & Prunus cerasifera Ehrh. \\
\hline & Viburnum opulus L. & & Prunus spinosa L. \\
\hline Celastraceae & Euonymus europaeus L. & & Pyrus pyraster (L.) Burgsd. \\
\hline Cornaceae & Cornus mas L. & & Rosa canina $\mathrm{L}$. \\
\hline
\end{tabular}


E. Delić, B. Dorbić, Nađa Buturović, Azra Bostandžić, Almina Tahirović / Prikaz modela za održavanje terenske nastave iz primijenjene botanike i ekologije / Glasilo Future (2019) 2 (4) 21-35

\begin{tabular}{|c|c|c|c|}
\hline Porodica & Rod i vrsta & Porodica & Rod $i$ vrsta \\
\hline Cornaceae & Cornus sanguinea $\mathrm{L}$. & \multirow[t]{5}{*}{ Rosaceae } & Rubus fruticosus L. \\
\hline \multirow[t]{2}{*}{ Cupressaceae } & Juniperus communis L. & & Sorbus aria (L.) Crantz \\
\hline & Thuja occidentalis L. & & Sorbus torminalis (L.) Crantz \\
\hline Dipsacaceae & Knautia drymeia & & Geum urbanum \\
\hline Ericaceae & Vaccinium myrtillus L. & & Crataegus laevigata (Poir.) DC. \\
\hline \multirow[t]{4}{*}{ Fabaceae } & Amorpha fruticosa $\mathrm{L}$. & Rubiaceae & Galium palustre \\
\hline & Chamaecytitus hirsutus (L.) Link & Ruscaceae & Ruscus aculeatus $L$ \\
\hline & Coronilla emerus L. & Rutaceae & Dictamnus albus \\
\hline & Robinia pseudoacacia L. & \multirow[t]{8}{*}{ Salicaceae } & Populus alba L. \\
\hline \multirow[t]{5}{*}{ Fagaceae } & $\begin{array}{l}\text { Fagus moesiaca (Domin, Maly) } \\
\text { Czecz.). }\end{array}$ & & Populus nigra $\mathrm{L}$. \\
\hline & Quercus cerris $\mathrm{L}$. & & Populus tremula L. \\
\hline & Quercus petraea (Matt.) Liebl. & & Salix alba L. \\
\hline & Quercus pubescens Willd. & & Salix caprea L. \\
\hline & Quercus robur $\mathrm{L}$. & & Salix elaeagnos Scop. \\
\hline Iridaceae & Iris pseudacorus & & Salix fragilis $\mathrm{L}$. \\
\hline \multirow[t]{2}{*}{ Juglandaceae } & Juglans nigra L. & & Salix purpurea L. \\
\hline & Juglans regia $\mathrm{L}$. & Simaroubaceae & $\begin{array}{l}\text { Ailanthus altissima (Mill.) } \\
\text { Swingle }\end{array}$ \\
\hline \multirow[t]{6}{*}{ Lamiaceae } & Lamium galeobdolon & Thymelaeaceae & Daphne mezereum L. \\
\hline & Melittis melissophyllum & \multirow{3}{*}{ Tiliaceae } & Tilia cordata Mill. \\
\hline & Ajuga reptans & & Tilia platyphyllos Scop. \\
\hline & Betonica officinalis & & Tilia tomentosa Moench \\
\hline & Clinopodium vulgare & \multirow[t]{3}{*}{ Ulmaceae } & Ulmus glabra Huds \\
\hline & Glechoma hederacea & & Ulmus laevis Pall. \\
\hline Moraceae & Morus alba L. & & Ulmus minor Mill. \\
\hline
\end{tabular}

\section{Osnove pedologije}

U okviru pedologije, studenti su dobili teoretska saznanja o najvažnijim faktorima koji utječu u formiranju tla, njegovim fizičkim, kemijskim i biološkim svojstvima. Također su se upoznali s najvažnijim tipovima šumskog tla, plodnosti i produktivnosti tla te mikro i makro elementima, neophodnim za rast i razvoj biljnih vrsta.

Praktični dio imao je za cilj da studenti na terenu samostalno opišu tip tla, njegove fizičke, kemijske i biološke karakteristike. Nakon terenskog dijela, studenti su sudjelovali i u praktičnim radionicama, gdje su dobili na uvid nekoliko uzoraka zemljišta sa zadatkom da na osnovi mehaničkog sastava (teksture tla), ljepljivosti tla, gustoće tla i reakcije tla odrede o kojem se tipu tla radi i koje bi vrste drveća na njemu najbolje uspijevale (Slika 4). 
E. Delić, B. Dorbić, Nađa Buturović, Azra Bostandžić, Almina Tahirović / Prikaz modela za održavanje terenske nastave iz primijenjene botanike i ekologije / Glasilo Future (2019) 2 (4) 21-35

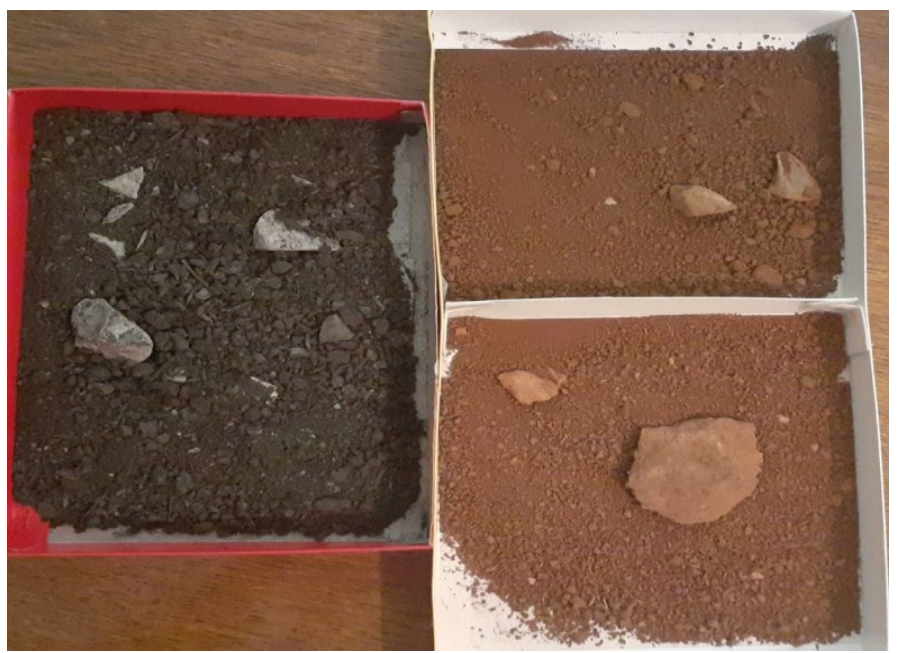

Slika 4. Odabrane vrste tala za vježbu (Foto: Emir Delić) Figure 4. Selected types of soils for exercise (Photo: Emir Delić)

Područje Eko-centra "Jezera" kao što je već i spomenuto nalazi se u nizinskom vegetacijskom pojasu, u zoni poplavnih (ritskih šuma) (Slika 6). Najugroženija vrsta kao posljedica djelovanja čovjeka, a nešto manje klimatskih promjena je europska crna topola (Populus nigra L.) koja se smatra vrstom u nestajanju iz dva razloga: 1) zbog prisustva gena američke crne topole (Populus deltoides W. Bartram ex Marshall.), u populacijama europske crne topole (P. nigra); 2) prirodne populacije ove vrste znatno su smanjene pod utjecajem čovjeka, izravnom sječom ili zahvatima u staništu (regulacija velikih tokova rijeka, izgradnja nasipa i zaštita obala), što je prouzrokovalo sprječavanje plavljenja i uvjetovalo fragmentaciju ritskih staništa te izumiranje autohtone vrste topole, čija je prirodna obnova onemogućena. Navedena vrsta se ubraja u najugroženije drvenaste vrste Europe.

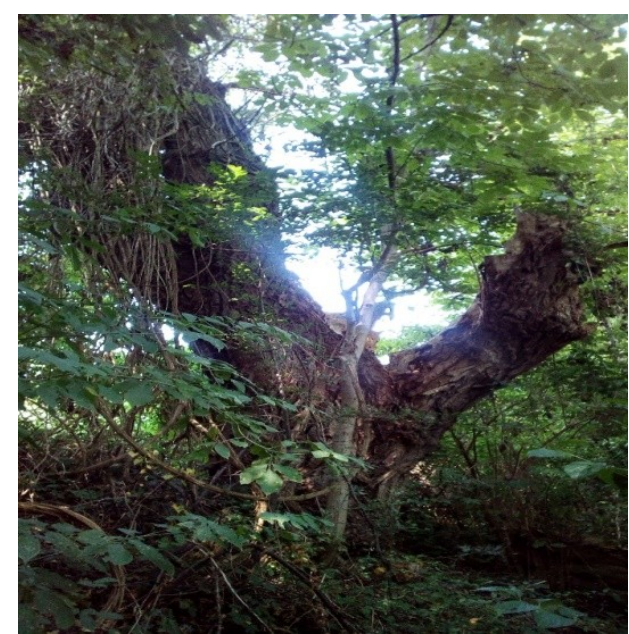

Slika 5. Populus nigra L. (Foto: Emir Delić)

Figure 5. Populus nigra L. (Photo: Emir Delić)

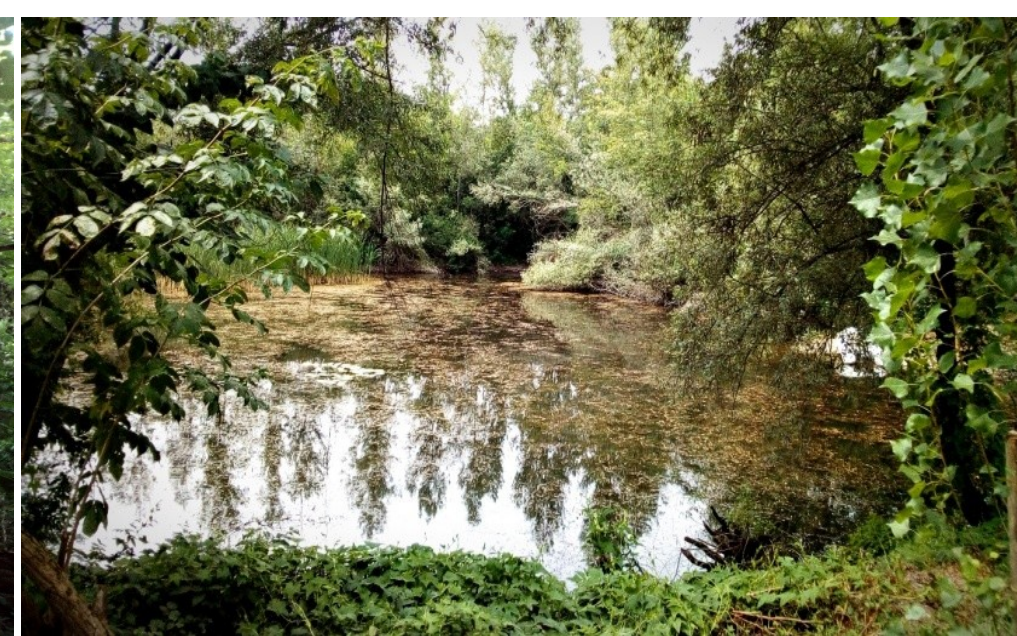

Slika 6. Poplavne šume (higrofilna vegetacija) na području Eko-centra "Jezera" (Foto: Emir Delić)

Figure 6. Flood forests (hygrophilic vegetation) in the area of Eko-centar Jezera (Photo: Emir Delić) 
E. Delić, B. Dorbić, Nađa Buturović, Azra Bostandžić, Almina Tahirović / Prikaz modela za održavanje terenske nastave iz primijenjene botanike i ekologije / Glasilo Future (2019) 2 (4) 21-35

Na području Eko-centra pronađena su dva primjerka autohtone crne topole još iz vremena dok je Drina tekla ovim područjem, procijenjene starosti od oko 150 do 200 godina (Slika 5). Njihov opseg debla iznosi otprilike 3 metra. Ostale jedinke čovjek je devastirao izravnom sječom.

\section{Rezultati anketnog istraživanja}

Rezultati anketnog istraživanja su prikazani $u$ dolje navedenim komentarima prema tablicama $(3,4,5 \mathrm{i}$ $6)$.

Tablica 3. Percepcija o kvaliteti, interesu i korisnosti terenske nastave iz područja dendrologije i ekologije šuma.

Table 3. The perception of quality, interest and usefulness of field work in the field of dendrology and forest ecology.

\begin{tabular}{|c|c|c|c|c|}
\hline R. br. & Pitanje & $\begin{array}{l}\text { Aritm. } \\
\text { sredina }\end{array}$ & $\begin{array}{c}\text { Stand. } \\
\text { devijacija }\end{array}$ & Varijanca \\
\hline 1. & $\begin{array}{l}\text { Procijenite kvalitetu održane terenske } \\
\text { nastave iz područja dendrologije i } \\
\text { sjemenarstva }\end{array}$ & 5,00 &, 000 & ,000 \\
\hline 2. & $\begin{array}{l}\text { Procijenite kvalitetu održane terenske } \\
\text { nastave iz područja šmarske } \\
\text { fitocenologije }\end{array}$ & 5,00 & ,000 & ,000 \\
\hline 3. & $\begin{array}{l}\text { Procijenite kvalitetu održane terenske } \\
\text { nastave iz područja ekologije šuma } \\
\text { (̌́umarska fitocenologija i Osnova } \\
\text { pedologije) }\end{array}$ & 5,00 & ,000 & ,000 \\
\hline 4. & $\begin{array}{l}\text { Procijenite kvalitetu metodologije } \\
\text { izvođenja terenske nastave }\end{array}$ & 5,00 & ,000 & ,000 \\
\hline 5. & $\begin{array}{l}\text { Procijenite korisnost terenske nastave } \\
\text { za Vaš budući rad u struci }\end{array}$ & 4,86 & ,378 & ,143 \\
\hline 6. & $\begin{array}{l}\text { Procijenite Vaš interes da nakon ove } \\
\text { terenske nastave posjetite botaničku } \\
\text { sekciju na biološkom kampu sljedeće } \\
\text { godine }\end{array}$ & 5,00 & ,000 &, 000 \\
\hline
\end{tabular}

Iz tablice 3. razvidno je da su studenti s ocjenom odličan ocijenili kvalitetu nastave iz svih bioekoloških područja, kao i korisnost ovakvog tipa nastave za njihov budući rad u struci. Rezultati pokazuju i to da iduće godine žele ponovno pohađati ovu sekciju. 
E. Delić, B. Dorbić, Nađa Buturović, Azra Bostandžić, Almina Tahirović / Prikaz modela za održavanje terenske nastave iz primijenjene botanike i ekologije / Glasilo Future (2019) 2 (4) 21-35

Tablica 4. Samoprocjena nivoa usvojenog znanja iz područja dendrologije.

Table 4. Self-assessment of the level of acquired knowledge in the field of dendrology.

\begin{tabular}{|l|l|c|c|c|}
\hline R. br. & Pitanje & $\begin{array}{c}\text { Aritm. } \\
\text { sredina }\end{array}$ & $\begin{array}{c}\text { Stand. } \\
\text { devijacija }\end{array}$ & Varijanca \\
\hline 1. & $\begin{array}{l}\text { Prepoznavanje pupova kritosjemenjača } \\
\text { s ovog područja i šire }\end{array}$ & 4,43 &, 535 &, 286 \\
\hline 2. & $\begin{array}{l}\text { Prepoznavanje kore raznih drvenastih } \\
\text { vrsta s ovog područja i šire }\end{array}$ & 4,43 &, 535 &, 286 \\
\hline 3. & $\begin{array}{l}\text { Prepoznavanje listova i habitusa raznih } \\
\text { drvenastih vrsta s ovog područja i šire }\end{array}$ & 4,29 &, 951 &, 905 \\
\hline 4. & $\begin{array}{l}\text { Prepoznavanje sjemena raznih } \\
\text { dendroloških vrsta s ovog područja i } \\
\text { sire }\end{array}$ & 4,71 &, 951 &, 905 \\
\hline 5. & $\begin{array}{l}\text { Procijenite nivo usvojenog znanja iz } \\
\text { dijela biologije i ekologije drvenastih } \\
\text { vrsta s ovog područja i šire }\end{array}$ & 4,57 &, 535 &, 286 \\
\hline
\end{tabular}

Iz tablice 4. se uočava da su studenti vrlo dobre (iznad 4,29) i odlične ocjene dodijelili samoprocjeni nivoa usvojenog znanja iz područja dendrologije.

Tablica 5. Samoprocijena nivoa usvojenog znanja iz područja šumarske fitocenologije

Table 5. Self-assessment of the level of acquired knowledge in the field of forest phytocenology

\begin{tabular}{|l|l|c|c|c|}
\hline R. br. & Pitanje & $\begin{array}{c}\text { Aritm. } \\
\text { sredina }\end{array}$ & $\begin{array}{c}\text { Stand. } \\
\text { devijacija }\end{array}$ & Varijanca \\
\hline 1. & $\begin{array}{l}\text { Procijenite nivo usvojenog znanja iz } \\
\text { dijela sindinamike }\end{array}$ & 3,71 &, 488 &, 238 \\
\hline 2. & $\begin{array}{l}\text { Procijenite nivo usvojenog znanja iz } \\
\text { dijela sinmorfologije }\end{array}$ & 3,86 &, 378 &, 143 \\
\hline 3. & $\begin{array}{l}\text { Procijenite nivo usvojenog znanja iz } \\
\text { dijela invanzivnih vrsta }\end{array}$ & 4,43 &, 787 &, 619 \\
\hline 4. & $\begin{array}{l}\text { Procijenite nivo usvojenog znanja iz } \\
\text { dijela izrade fitocenološkog snimka }\end{array}$ & 3,43 & 1,272 & 1,619 \\
\hline 5. & $\begin{array}{l}\text { Procijenite nivo usvojenog znanja iz } \\
\text { dijela taksona nižih od vrsta }\end{array}$ & 3,71 &, 756 &, 571 \\
\hline 6. & $\begin{array}{l}\text { Procijenite nivo usvojenog znanja iz } \\
\text { dijela sinhorologije }\end{array}$ & 3,71 &, 756 &, 571 \\
\hline
\end{tabular}

Prema tablici 5. vidi se da su u području Šumske fitocenologije studenti dodijelili nešto niže ocjene u samoprocjeni znanja (vrlo dobar). Najveća ocjena je dodijeljena nivou usvojenih znanja iz područja invazivnih vrsta, za koji se pretpostavlja da su o tome dobili više prethodnih informacija na studiju biologije. 
E. Delić, B. Dorbić, Nađa Buturović, Azra Bostandžić, Almina Tahirović / Prikaz modela za održavanje terenske nastave iz primijenjene botanike i ekologije / Glasilo Future (2019) 2 (4) 21-35

Tablica 6. Samoprocjena nivoa usvojenog znanja iz područja ekologije šuma

Table 6. Self-assessment of the level of acquired knowledge in the field of forest ecology

\begin{tabular}{|l|l|c|c|c|}
\hline R. br. & Pitanje & $\begin{array}{c}\text { Aritm. } \\
\text { sredina }\end{array}$ & $\begin{array}{c}\text { Stand. } \\
\text { Devijacija }\end{array}$ & Varijanca \\
\hline 1. & $\begin{array}{l}\text { Procijenite nivo usvojenog znanja iz } \\
\text { dijela osnova pedologije }\end{array}$ & 3,86 & 1,069 & 1,143 \\
\hline 2. & $\begin{array}{l}\text { Procijenite nivo usvojenog znanja iz } \\
\text { dijela sistematike šumskih tala }\end{array}$ & 4,29 & 1,113 & 1,238 \\
\hline 3. & $\begin{array}{l}\text { Procijenite nivo usvojenog znanja iz } \\
\text { dijela problematike šumskih požara }\end{array}$ & 3,71 &, 756 &, 571 \\
\hline 4. & $\begin{array}{l}\text { Procijenite nivo usvojenog znanja iz } \\
\text { dijela zaštićenih i ugroženih biljnih } \\
\text { vrsta Bosne i Hercegovine }\end{array}$ & 3,57 &, 535 &, 286 \\
\hline
\end{tabular}

Iz tablice 6. je razvidno da su studenti najbolje procijenili nivo usvojenih znanja iz dijela sistematike šumskih tala što se može povezati s praktičnim pokaznim vježbama na terenu. Potom slijedi samoprocjena usvojenog znanja iz osnova pedologije, ocjena vrlo dobar $(3,86)$ te ostale procijene iz ovog područja koje su također ocijenjene s vrlo dobrim.

Praktična nastava se može odnositi na obradu novog nastavnog sadržaja, kao i na i ponavljanje već obrađenog gradiva. Ukoliko se radi o terenu, prije samog izlaska na terensku nastavu mora se napraviti i organizacija nastave (Žujo Zekić, 2017). Iz dobivenih rezultata ustanovljeno je da su studenti s ocjenom odličan ocijenili kvalitetu nastave iz svih bio-ekoloških područja, kao i korisnost ovakvog tipa nastave za njihov budući rad u struci. Rezultati pokazuju i to da sljedeće godine polaznici žele ponovno pohađati ovu sekciju. Rezultati drugih istraživanja su pokazali da npr. učenici nekih zagrebačkih osnovnih škola više preferiraju izvanučioničku nastavu u prirodi, nego izvanučioničku nastavu koja se ne održava u prirodi (Sever et al., 2017).

Rezultati ovog istraživanja su pokazali da su studenti vrlo dobre i odlične ocjene dodijelili samo procijeni nivoa usvojenog znanja iz područja dendrologije, dok je nivo samovrednovanja znanja iz šumarske fitocenologije ocijenjen s vrlo dobrim ocjenama. Navedeno se može povezati s prethodno stečenim znanjima sa studija gdje se više obrađivala sistematika bilja u okviru botaničke grupe predmeta. Također je korištenje bioloških zbirki, koje predstavljaju odličan sustav demonstracije pridonijelo lakšem usvajanju znanja iz područja dendrologije. Slično potkrjepljuju i drugi autori, npr. Dorbić et al., 2013.

Svrha demonstracije bioloških zbirki je način za osposobljavanje samostalnog promatranja i primjenu logičkih operacija u samostalnom stjecanju predodžbi o živom svijetu (Bašić, 2001., prema., Žujo Zekić, 2017). 
E. Delić, B. Dorbić, Nađa Buturović, Azra Bostandžić, Almina Tahirović / Prikaz modela za održavanje terenske nastave iz primijenjene botanike i ekologije / Glasilo Future (2019) 2 (4) 21-35

Dobiveni vrlo dobri rezultati u anketnom istraživanju o samoprocjeni znanja iz dijela sistematike šumskih tala mogu se povezati s praktičnim pokaznim vježbama na terenu. Neka prethodna istraživanja su potvrdila da npr. učenici stječu trajna znanja učeći na primarnim izvorima znanja jer nijedna slika, crtež ili video snimak ne mogu biti tako vjerodostojni kao prirodni materijal (Ademović et al., 2018).

Općenito rezimirajući gore navedeno, zadatak suvremene nastave je priprema učenika za cjeloživotno obrazovanje. Kako bi to bilo moguće ostvariti, važno je mijenjati i ulogu učitelja te uvesti promjene u nastavi i nastavnom procesu (Bašić, 2001., prema., Žujo Zekić, 2018).

Proučavajući povezivanje nastavnih metoda sa prosječnim postotkom njihova uticaja na zapamćivanje William Glasser (2005) izrađuje svoju poznatu piramidu. Idući od vrha prema dnu njegove piramide zaključujemo da usmenim izlaganjem nastavnika učenici će zapamtiti oko $20 \%$, demonstracijom oko $50 \%$, a kroz praktični rad i primjenu naučenog čak 80 \% (Ademović et al., 2018). Rezultati anketnog istraživanja u ovom radu su potvrdila početnu pretpostavku da ovakav tip nastave studenti u većoj mjeri podupiru i lakše usvajaju dobivena znanja.

\section{Zaključak}

Shodno prikazanom modelu terenske nastave koja se održala u Eko centru "Jezera". nedaleko od Bijeljine (BIH), dobiveni rezultati anketnih istraživanja studenata su pokazala da su studenti s ocjenom odličan ocijenili kvalitetu nastave iz svih bio-ekoloških područja. Samoprocjena znanja studenata je pokazala da su studenti najbolje ocjene dodijelili nivou znanja iz područja dendrologije. Rezultati anketnog istraživanja su potvrdila početnu hipotezu da ovaj tip nastave studenti u većoj mjeri podupiru i lakše usvajaju nastavno gradivo.

\section{Literatura}

Ademović, E., Žujo Zekić, D., Martinović, M. (2018). Savremena nastava kao izazov za opstanak bioloških zbirki u nastavi biologije. Educa, 11(11), 245-249.

Bašić, M. (2001). Metodika nastave biologije (I izdanje). Zenica: Dom štampe.

Bogut, I., Popović, Ž. i Mikuška, A. (2017). The role and importance of outdoor teaching and fieldwork in biology for primary school teacher education. Život $i$ škola, LXIII (2), 127-132.

Dorbić, B., Frua, Lj., Zubac, J., Šuste, M., Pamuković, A. i Vrdoljak, M. (2013). Vrt Veleučilišta u Kninu - Ugoda i istraživački rad. Agronomski glasnik, 75(5-6), 304-318. 
E. Delić, B. Dorbić, Nađa Buturović, Azra Bostandžić, Almina Tahirović / Prikaz modela za održavanje terenske nastave iz primijenjene botanike i ekologije / Glasilo Future (2019) 2 (4) 21-35

Dorbić, B., Davitkovska, M., Temim, E., Pamuković, A. (2018). Ukrasno bilje-Uzgoj i primjena. Šibenik: Ogranak Matice hrvatske u Šibeniku.

Franjić J., Škvorc Ž. (2010). Šumsko drveće i grmlje Hrvatske, Zagreb: Sveučilište u Zagrebu, Šumarski fakultet.

Glasser, W. (2005): Kvalitetna škola. Zagreb: Educa.

Gurda, S. (1999). Tehnologija drveta. Sarajevo: Šumarski fakultet Sarajevo

Husanović-Pejnović, D. (2011). Održivi razvoj i izvanučionička nastava u zavičaju, Zagreb: Školska knjiga.

Idžojtić, M. (2005). Listopadno drveće i grmlje u zimskom razdoblju. Zagreb: Sveučilište u Zagrebu, Šumarski fakultet. Idžojtić,

Idžojtić, M. (2009). Dendrologija - List. Zagreb: Sveučilište u Zagrebu, Šumarski fakultet.

Idžojtić, M. (2013). Dendrologija - cvijet, češer, plod, sjeme. Zagreb: Sveučilište u Zagrebu, Šumarski fakultet.

Kajba, D., Ballian, D. (2007). Šumarska genetika. Zagreb - Sarajevo: Šumarski fakultet Sarajevo.

Mataruga, M., Isajev, V., Orlović, S. (2013). Šumski genetički resursi. Banja Luka: Univerzitet u Banjoj Luci, Šumarski fakultet.

Medak, J. (2018). Šume bukve, Javna ustanova "Park prirode Velebit".

Mekić, F. (1997). Sjemenarstvo u šumarstvu. Sarajevo: Šumarski fakultet Univerziteta u Sarajevu.

Mekić, F. (1998). Rasadnici i nasadi. Sarajevo: Šumarski fakultet Univerziteta u Sarajevu.

Sever, I., Vranić, M., Bošnjak, K., Čačić, I., Protulipac, M., Klepac, M. (2017). Procjene učitelja i učenika o izvanučioničkoj nastavi u prirodi u osnovnim školama grada Zagreba. Metodički ogledi, 24(1), 95-108.

Stefanović, V. (1977). Fitocenologija sa pregledom šumskih fitocenoza Jugoslavije. Sarajevo: IGKRO "Svjetlost".

Šag, M., Turić, N., Čerba, D. i Turković Čakalić, I. (2016). U potrazi za jelenkom (Lucanus cervus Linnaeus, 1758) - Primjer izvanučioničke nastave. Educatio biologiae, (2), 67-77.

Šilić, Č. (1990-a.). Ukrasno drveće i grmlje. Sarajevo: Svjetlost.

Šilić, Č. (1990-b.). Atlas drveća i grmlja. Sarajevo: Svjetlost. 
E. Delić, B. Dorbić, Nađa Buturović, Azra Bostandžić, Almina Tahirović / Prikaz modela za održavanje terenske nastave iz primijenjene botanike i ekologije / Glasilo Future (2019) 2 (4) 21-35

Šilić, Č. (2005). Atlas dendroflore (drveće i grmlje) Bosne i Hercegovine. Čitluk: Matica hrvatska.

Takač, M. (2013), Izvanučionička nastava - škola u prirodi. Diplomski rad. Odsjek za učiteljske studije, Učiteljski fakultet, Sveučilište u Zagrebu.

Vojniković, S., Bašić N., Beus, V. (2017). Atlas šumske vegetacije i dendroflore Bosne i Hercegovine $i$ susjednih područja. Sarajevo: Šumarski fakultet Univerziteta u Sarajevu, Akademija nauka i umjetnosti Bosne i Hercegovine.

Vukelić, J., Gračan, J., Dundović, J. (2001). Obična jela u Hrvatskoj / Silver fir in Croatia, Hrvatske šume.

Žujo Zekić, D., Ademović, E., Boškailo, A., Gajević, M. (2018). Savremeni pristupi praktičnom radu u nastavi biologije. Educa 11(11), $361-365$.

Primljeno: 06. prosinca 2019. godine

Received: December 06, 2019

Prihvaćeno: 30. prosinca 2019. godine

Accepted: December 30, 2019 